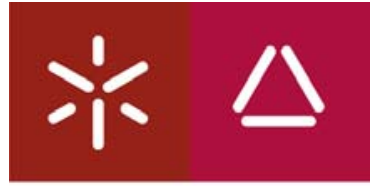

Universidade do Minho Instituto de Ciências Sociais
Centro de Estudos de Comunicação e Sociedade www.cecs.uminho.pt

\title{
The Liberalisation of Media and Communications in Portugal *
}

\author{
Helena Sousa \\ Professora Associada
}

helena@ics.uminho.pt

Universidade do Minho

Centro de Estudos de Comunicação e Sociedade

Campus de Gualtar

4710-057 Braga

Portugal

"SOUSA, H. (2002) «The Liberalisation of Media and Communications in Portugal» in Syrett, Stephen (Coord.), Contemporary Portugal, Dimensions of economic and political change, Hampshire (UH) \& Burlington (USA), Ashgate. 
Palvaras-chave

Media, Liberalização, Política da Comunicação, Regulação, Cavaco Silva, António Guterres, Portugal

\section{Abstract}

The Socialist government led by António Guterres (1995-1999) has thus inherited highly reformed but poorly regulated media and telecommunications sectors, and - so far - no structural communications policies were either announced or introduced. Basically, the Guterres government is following EU policies, attempting to strengthen existing regulatory bodies, and trying to improve a number of legal instruments. In this paper, we will start by presenting an historical perspective of the Portuguese media and telecommunications. Then, we shall look at the internal and external factors which partly explain the structural changes introduced in both sectors during the Cavaco Silva's governments. After putting forward some of the most relevant aspects of the PSD communications reforms, we will turn our attention to the political intervention of the first Guterres’ government in this arena.

\section{The Liberalisation of Media and Communications in Portugal}

Paper delivered at the 'Portugal at the Millennium Conference' organised by the Centre for Enterprise and Economic Development Research/Middlesex University, Canning House, London, 21st May 1999.

The most comprehensive changes in the Portuguese communications, since the 1974-75 revolutionary period, were undertaken by the Social Democrats (Partido Social Democrata - PSD) during the absolute majority rule from 1987 up to 1995 . Given the nature of political, economic and technological developments, changes in media and telecommunications were bound to be introduced. At the regional level, the European Union was developing policies in this area; conservative governments in the UK, 
Germany and France persuasively argued for the liberalisation of markets and privatisation of state property. Important technological advances - mainly the development of satellite and optic fibre and the subsequent convergence of distribution technologies - had major implications.

At a national level, significant changes were also taking place: the economy was growing and the liberalisation of the media and telecommunications markets were perceived as inevitable. Furthermore, the pro-business approach of the PSD governments - led by Cavaco Silva - favoured the privatisation of state media and telecommunications companies. Indeed, under the Social Democrats majority governments, newspapers which had been nationalised during the revolutionary period, returned to private hands. The radio sector was liberalised and one public radio station was privatised. The television public service operator lost the monopoly as two national television companies were allowed to operate television commercial channels. Similarly, and in line with EU policies, the telecommunications market was opened up to new actors and the three public telecommunications operators were merged and later privatised.

The Socialist government led by António Guterres (1995-1999) has thus inherited highly reformed but poorly regulated media and telecommunications sectors, and - so far - no structural communications policies were either announced or introduced. Basically, the Guterres government is following EU policies, attempting to strengthen existing regulatory bodies, and trying to improve a number of legal instruments.

In this paper, we will start by presenting an historical perspective of the Portuguese media and telecommunications. Then, we shall look at the internal and external factors which partly explain the structural changes introduced in both sectors during the Cavaco Silva's governments. After putting forward some of the most relevant aspects of the PSD communications reforms, we will turn our attention to the political intervention of the first Guterres’ government in this arena. 


\section{Media Recent History}

After the 1974 revolution, the media endured major convulsions. Precensorship was immediately abolished whilst a ferocious confrontation for the control of the most important media had just started. Very different factions co-existed within the so-called 'winners' of the revolution. Hence, no consensus would be easily achieved as to what role the media should play in a post-dictatorial society and a chaotic situation could hardly have been avoided.

Mesquita et al. ${ }^{\mathrm{i}}$ identify three conflicting tendencies in the aftermath of the revolution:

- The inheritors of the old regime who tried to postpone the dismantling of censorship mechanisms. In terms of further legislation, this faction was in favour of a posteriori repressive measures ${ }^{\mathrm{ii}}$;

- The defenders of revolutionary Marxist ideas who were also favourable to $a$ posteriori censorship;

- The adherents of a pluralist concept of the media, based on a Western model of democracy. This faction argued for the abolition of any form of censorship mechanisms, arguing that the courts would be the appropriate stage for media disputes.

Notwithstanding these conflicting views, two major pieces of legislation approved after 1974 were strongly against the control of the media by any form. The 1975 Press Law ${ }^{\text {iii }}$ guaranteed that the 'press freedom will be exercised without subordination to any form of censorship' (Art.4 $4^{\circ}$ ). Similarly, the 1976 Constitution suggested that the pluralist view of the media was clearly successful. It stated that the freedom of the press was guaranteed and that no group was allowed to exercise censorship or obstruct journalistic creativity (Art. $39^{\circ}$ ). These documents could be understood as pluralist, in the sense that they expressed the view that different interests in society should have the right to express themselves and to influence the political process. But, if this view succeeded in legal terms, a very different non-expressed policy was being implemented.

Arguably because of the dangerous 'reactionary forces', leftist elements within the Movimento das Forças Armadas (MFA) contended that the media would have to be 
controlled during the revolutionary period. There was a clear contradiction in the MFA programme which contemplated both the 'abolishment of censorship and previous examination' and the creation of an 'ad hoc committee to control the press, radio, television, theatre and cinema' in order to 'safeguard military secrets and to prevent disturbances which could be provoked in public opinion by ideological aggressions from the most reactionary sections of society ${ }^{\text {iv }}$.

This ad hoc committee transformed itself enormously, according to which faction was more powerful within the MFA movement and within the Junta de Salvação Nacional. First, radical leftist media were censored but, with the removal of the more conservative General Spínola, after the 28th of September crisis, the leftist wing gained progressive strength and the ad hoc Committee concentrated its activity among the rightist/conservative press. From the 6th of September 1974 to the 28th of February 1975, 28 publications were suspended whose majority was close to the Catholic Church ${ }^{\mathrm{v}}$.

The battle for media control right after the revolution and, particularly, after the 28th of September, was far from being fought only within the ad hoc Committee which had powers to suspend and punish newspapers which were out of the leftist 'revolutionary' line. Elements close to the MFA movement were appointed to leading posts both in radio and television. By early 1975, the panorama in the electronic media was perceived as being chaotic. In Salgado Zenha's words, 'what is now going on in the Emissora Nacional and on television is very grave because there is no single censorship but several $^{\prime v i}$. This highly volatile situation got even worse with the installation of the communist provisional governments of Vasco Gonçalves, after the 11th of March coup. The publication of the pluralist Press Law, the month before, did not prevent the increasing levels of media instrumentation.

In addition to the creation of a Press Council (Conselho de Imprensa) to safeguard press freedom, the Press Law contemplated extensive guarantees for journalists such as freedom to inform, freedom of thought, freedom of access to official sources of information, freedom of publication, among others. This legislation was however in clear contradiction with the Vasco Gonçalves' view of a communist society. So, in parallel with this law, the Social Communication minister, Vitor Alves, has created a new organism, the Conselho de Informação. The creation of this council was 
justified by the need of 'an ample and internal debate and inter-change of ideas between the ministry of Social Communication and the State's media'vii . In reality, the goals of Conselho de Informação were directly related with the Communist Party's intention to decide directly the state's media agenda and discourse. The Rádiotelevisão Portuguesa (RTP) and Emissora Nacional (EN), in particular, were to be used in the construction of a 'People's democracy'.

Indeed, in this revolutionary period, the press which was still in private hands was 'transferred' to public ownership. Three days after the leftist coup of 15th March 1975, important sectors of the economy such as banking and insurance were nationalised. Because many leading newspapers were owned by strong economic groups and banks, they became state property. 'From the important dailies, only the República in Lisbon and O Primeiro de Janeiro, in Oporto remained in private hands'viii. The nationalisation of the press was never explained as a political option. 'It was presented as an indirect consequence of the nationalisation of the banking sector ${ }^{\mathrm{ix}}$. But behind this option was clearly the will to control what was left out of government's direct influence. Significantly, the nationalisation process was not reversed with the removal of the communist prime minister, Vasco Gonçalves, in November 1975.

Under Gonçalvismo, the electronic media were directly controlled by leftist forces, but the 'moderate' VI provisional government would only increase the state's media ownership. Radio was nationalised, with the exception of the Catholic Rádio Renascença (RR) which had been in communist's hands during Vasco Gonçalves's governments. The newly created national radio company was called Empresa Pública de Rádiodifusão (EPR), although it would later be re-named Rádiodifusão Portuguesa (RDP). RDP and RR came to be known as the radio duopoly which remained untouched until the explosion of illegal radio stations in the mid-1980's. The television company RTP (Rádiotelevisão Portuguesa, SARL) which had been managed directly by the government since the coup (law-decree $n^{\circ}$ 278/74) was also nationalised by late 1975 (law-decree $n^{0}$ 674-D/75 of 02.12.75), being established as the public company RTPRádiotelevisão Portuguesa, EP. The RTP monopoly only ended with the opening up of TV channels to private initiative in the early 1990's.

Both RDP and RTP have been under the control of successive governments. 'Clear evidence of this is given by the fact that since 1974 the eleven seats on the board 
of governors and the 20 directors posts at RTP and RDP have been held by 80 and 130 different people respectively, whose qualifications for the job were considered less important than their party membership cards' ${ }^{\prime \mathbf{X}}$. Indeed, administrations have changed even more frequently than governments. The height of that instability was reached during the three and a half years of the Aliança Democrática (AD) which made the most blatant move to put radio and television at the service of the government. In the words of the first chairman of the board appointed by the AD and $15^{\circ}$ President of RTP (from February 1980 to July 1980), Victor Cunha Rego, 'impartiality in state television was unthinkable ${ }^{x \mathrm{xi}}$.

What is particularly remarkable about the media development in Portugal is that laws drawn up during an exceptional period shaped the media until the 1980's. This aspect suggests that the authoritarian nature of the provisional leftist governments suited the newly created democrats. Despite the 1976 Constitution (with its impressive display of civil liberties), no elected government was prepared to grant freedom to the press. Generally, following the political measures introduced during the revolutionary period, politicians from all affiliations have not openly designed media policies but have merely taken the necessary steps to ensure that the nationalised media would be favourable to those in power.

\section{Telecommunications Recent History}

Although telecommunications are fundamental to the state's security and to the economic development, the Salazar regime paid little attention to civilian communications and maintained the basic market structure from the 1920's up until the 1960's. Marcello Caetano, on the contrary, perceived telecommunications as a means to help revive the economy and, in fact, from 1968 up until 1974, important investments were made in both internal and international telecommunications. But, despite investments, Portuguese telecommunications were still backward, when compared with most Western countries. 
From the 1974 revolution until the early 1980’s, no government introduced any significant change in the telecommunications sector. In 1981, a telecommunications reform was attempted and a significant Law Decree (188/81) was passed in accordance with the government programme $\mathrm{x}^{\mathrm{xii}}$. This piece of legislation recognised that until then the government had been unable to co-ordinate public communications operators due to a lack of infrastructures and contemplated the setting up of the Instituto Português das Comunicações (ICP) to support the Ministério das Obras Públicas Transportes e Comunicações (MOPTC) in the co-ordination of the telecommunications sector. Public postal and telecommunications services were to be maintained as a state monopoly, but the terminal equipment market was to be opened up to competition. Users of the public network were to be allowed to buy any terminal equipment approved by ICP.

With the legal creation of ICP, some aspects of separation between regulatory and operational functions were contemplated for the first time. Although the effective setting up of ICP was postponed, according to the approved legislation, it should have had a role as a political initiator and as technical assistant to the government. Among other things, the Institute - under the tutelage of the MOPTC - would have had to prepare legislation, supervise public operators, approve equipment and manage the radio spectrum. Yet, despite this legislative effort, there was no implementation of the law and the ICP was not actually established until 1989, after the approval of the Law Decree 283/89 which stated that ICP should start its activities within six months (Art. $\mathrm{n}^{\circ}$ 27). Apart from the political instability the country was in, the main reason why ICP did not start operating in the early or mid-1980's was related to the fact that the 9th Constitutional government (1983-1985) - led by the socialists - did not regard ICP favourably. In these circumstances, the liberalisation of terminal equipment, though contemplated in the law, did not materialise.

Still, at that time, it was widely accepted that Portuguese telecommunications were lagging behind and that digitalisation ${ }^{x i i}$ and optic fibre ${ }^{\text {xiv }}$ would have to be introduced if the country was to catch up with the EU core countries. If agreement could be achieved about the need to modernise and update the sector, no consensus was possible on the strategy to be followed. Some argued for a progressive introduction of new technologies so that the Portuguese industry ${ }^{\mathrm{xV}}$ could adapt, but the political power favoured rapid change. According to Tribolet ${ }^{\mathrm{xvi}}$, 'only big multi-nationals could supply public digital exchanges given that there was no internal industrial or technological 
basis to do it'. The 1983-1985 government decided to open up the switch contract bidding to seven different companies ${ }^{x i i}$ to 'demonstrate openness to the European Economic Community ${ }^{\text {xviii }}$.

The allocation of these large procurement orders for central electronic switches was a multi-year story of intrigue at many levels. At the time of the award of the contract, Centrel (a national manufacturing company) had just entered a joint venture with Siemens for the production of switches developed by the German firm. Alcatel's interests were personally pushed by President Mitterand (a personal friend of the then prime minister, Mário Soares). German politicians also got involved in similar lobbying for Siemens. A highly politicised inter-ministerial commission decided to allocate $55 \%$ of the order to Siemens and $35 \%$ to Alcatel, despite the latter's lack of Portuguese production facilities. The remaining $10 \%$ were allocated in a complex manner among the winner companies. The allegations of impropriety forced the first social democrat government (1985-87) to re-open the case. The Siemens/Centrel contract was maintained but Alcatel lost its share and Standard Electric received 45\% of the contract. When all seemed lost for Alcatel, its parent company, CGE, acquired controlling interests in most of ITT's international telecommunications operations, allowing Alcatel to crack the Portuguese market after all ${ }^{\mathrm{xix}}$.

In addition to the procurement contracts for digital exchanges, 1985 was also relevant for national telecommunications because the first optic fibre cable was installed allowing the future introduction of new services such as videoconferencing and cable $\mathrm{TV}^{\mathrm{xx}}$. The first Siemens' EWSD digital exchange was installed in June 1987 by TLP ${ }^{\mathrm{xxi}}$. Although the mid-1980's were a turning point in terms of network modernisation, it was done - as Tribolet ${ }^{\mathrm{xxii}}$ points out - without safeguarding Portuguese industrial capability. Yet, rapid technological change, even at the expense of the national telecommunications industry, was perceived as being of crucial importance on the eve of Portugal's entry into the Community. 


\section{Pressures for Change}

Given the nature of political, economic and technological developments in the mid1980 's, changes in the media and communications were bound to be introduced. At a regional level, the European Union was developing its policies for television and telecommunications as radio and the press were not high on the EU agenda. Conservative governments in the UK, Germany and France (not to mention the US) persuasively argued for liberalisation of markets and privatisation of state property. Last but certainly not least, important technological advances - mainly the development of satellite and optic fibre and the subsequent convergence of distribution technologies had enormous implications. The proliferation of European satellite TV channels, for instance, started being used as an argument against the national RTP monopoly. RTP's critics argued that, once one could receive international private TV channels, there was no reason why one should not have national private channels.

At a national level, important changes were also taking place. Up to the mid1980 's, the political instability in the country was so acute that any comprehensive set of political decisions was hard, if not impossible, to implement. In 1987, one year after Portugal joined the EEC, the first majority government was elected since the 1974 revolution. At that time, the country's economy was booming that being the main reason for a substantial rise in advertising revenue which had increased, in total, from around $£ 52$ million in 1986 to around $£ 400$ million in $1994^{\text {xxiii }}$. In this economic context, relatively unconstrained newspapers such as $O$ Independente and Público were set up and their existence seriously impaired the government's ability to suppress politically damaging material. In addition, the climate of opinion was turning against the concentration of the media in the state's hands. The Cavaco Silva's government itself believed that if Portugal was to be seen as a truly European partner, changes in the economy, and consequently in the media market, had to be introduced. A pro-business approach was taken and the liberalisation of the media market and privatisation of a substantial share of state media was imminent.

In Portuguese recent history, this would be the second time that a government opened up the media and picked winners. In the 1970's, Marcello Caetano tried to 
maintain power over the press by allowing economic groups close to the regime to own periodicals. As the country was supposedly opening up and censorship was bound to be abolished, Marcello Caetano urged economic groups to buy out newspapers. In a different context, in the late 1980's and early 1990's, Cavaco Silva carefully chose the actors which would be allowed to participate in the newly liberalised broadcasting market and privatised state press. In other words, if liberalisation and privatisation could not be avoided, the media should be in the safest possible hands.

External factors have also contributed to substantial changes in the telecommunications sector. By 1986, the EU telecommunications policy had already been designed around two contradictory trends: the support of the most competitive Information Technology (IT) companies through R\&D programmes and, following the US example, the endorsement of more competition and liberalisation of equipment and services. Therefore, since Portugal joined the EU, the pressure to modernise and reorganise the telecommunications sector has intensified and, on May 1986, Sequeira Braga, head of Secretaria de Estado dos Transportes e Comunicações (SETC), requested a study to examine Portuguese telecommunications and to report on the most pressing issues in this area. In May 1987, the Comissão para o Estudo do Desenvolvimento Institucional e Tecnológico das Comunicações (CEDITC) presented the study ${ }^{\mathrm{xxiv}}$ to the respective ministry, MOPTC.

This study argued that Portuguese telecommunications were lagging behind those of most European countries (by an estimated 15 years) and recommended the following changes:

- The Institute of Communications (ICP) should be inaugurated and regulatory functions should be transferred to this institute;

- A holding company should be set up to increase the efficiency of operators (CTT, TLP and Marconi). This company should guarantee a global and integrated strategy for the national telecommunications sector;

- Postal and telecommunications services should be separated. Until then, CTT covered both activities;

- Measures should be taken to prepare the opening up of telecommunications operators to private capital; 
- More flexibility should be introduced into new telecommunications services. Possibly, competition should be introduced;

- Prices should be liberalised in the non-basic telecommunications sub-sector.

These recommendations - which were broadly in line with what was being discussed at European level at the time - were largely adopted by the 11th Constitutional Government ${ }^{\mathrm{xxv}}$ and constituted an important input to the 1989 Basic Telecommunications Law. This basic law was a real watershed in the Portuguese telecommunications legal history because the general principles of this sector were, for the first time, compiled in the same piece of legislation. Since the 1987 CEDITC recommendations were published, there was a dramatic increase in political activity surrounding telecommunications.

\section{Opening up the Media Market}

The two PSD majority governments ${ }^{\text {xxvi }}$ undertook the most comprehensive changes in the media since 1974-75. Although the governmental programmes ${ }^{\text {xxvii }}$ were vague and did not clearly set out the government's objectives for the sector, the following lines of action could be identified in these two programmes:

- the nationalised press should return to the private sector

- a minimum radio and television public service should continue to be provided by the state

- the radio sector should be liberalised and/or privatised (e.g. Rádio Comercial) - a television act should be approved so two TV channels could be granted to private operators

- the national news agency, Lusa, should continue to be publicly owned

- attention should be given to the Portuguese communities abroad, to the Portuguese speaking peoples, and to the regional press and professional training.

Even if not expressed, some of these lines of action are still directly related to the control of content. The state's ownership and subsequent government's control of the 
national news agency (Lusa) for example, is crucial for the executive's dominion over political content both in the national and local media. This is mainly due to a lack of human and material resources in the media which forces them to rely heavily on Lusa. However, some policy proposals in this programme deal with structure of the media which is a shift from previous minority governments.

The first set of measures directly related to the structure of the media concerned the re-organisation of the radio broadcasting sector. By mid-1980's there were so may illegal radio stations operating that the government could no longer ignore that reality. Nevertheless, it was only in 1989 that 310 local frequencies were allocated. In the following year, two regional frequencies were attributed: one went to Rádio Press, part of the Lusomundo group and the other to Correio da Manhã Rádio which belonged to the Carlos Barbosa group. As early as 1976 there were calls for the legalisation of local and regional radio stations but no government was keen on doing so.

In 1991, the two most important state owned and controlled newspapers were privatised. The government had been following a wide privatisation programme and there were no grounds to justify the maintenance of Jornal de Notícias and Diário de Notícias under state control. The government was in a dilemma between the perceived need to control those newspapers and the ideological and political belief in privatisation. In a controversial process, both were bought by Lusomundo, one of the most important multi-media groups in Portugal, perceived - at the time - as having close links with the government.

In any case, the opening up of TV channels to private ownership was by far the most relevant aspect of Cavaco Silva's governments' media policy. Indeed, there has been considerable debate about private television, in particular, since the 1982 Constitutional changes. The 1976 Constitution states that no TV channel could be privately owned and the 1982 review did not contemplate any changes in this area. Nevertheless, it unleashed some controversy about the issue. The Catholic Church was one of the first actors to openly express its desire to own and run a private TV channel but the political and economic conditions were not favourable. 
From 1987 onwards, due to the economic growth and political stability, the Balsemão, Sonae and Presslivre groups started to seriously evaluate their possibilities in the new context. This process, however, was delayed until the early 1990's because the government had to concentrate its efforts on the re-organisation of the radio sector whose expansion had been chaotic since the mid-1980's. When local and regional radio frequencies were attributed, political interest moved again to private television.

The constitutional obstacles towards private television were removed on the 1st of June 1989 when the National Assembly approved amendments in the legislative text by a two thirds majority. The new text allowed TV channels to be privately owned. The next highly controversial step was the drafting of a new television act. Conflicting interests were at stake and, once again, the Catholic Church was in the centre of the polemic. The Church wanted to be granted a TV channel without participating in the bidding process. So, when the government's law proposal was known, the Portuguese bishops went publicly against the government saying that 'the law proposal does not correspond to former commitments and to what was expected, it does not safeguard the Church's rights consigned in the Constitution' ${ }^{\text {'xxviii }}$. In the 1970's, the Church had been granted an assurance by the former prime minister, Sá Carneiro, that it would be attributed a television channel. Hence, the religious leaders felt they were now being unfairly treated. The Catholic Church's Rádio Renascença network was used to put these arguments forward and clerics throughout the country were given the task of reading and commenting on the bishops' position.

In the middle of these serious rows and hot debates, Parliament approved a new television law on the 13th of July 1990 which did not contemplate any privileged position for the Catholic Church, but it also did not prevent the Church, in any way, from applying for a channel. The law says that 'the activity of television cannot be exercised and financed by political parties or associations, unions, professional and employers organisations, and by local authorities' (law $\mathrm{n}^{\circ}$ 58/90, Art.3 $3^{\circ}$ ). Still, significantly, religious organisations were not mentioned in this law. So, the Catholic Church was allowed to enter the competition.

Once the new television law was passed and the bidding regulations approved, on the 2nd of April 1991, three candidates applied for the two available national TV channels: the Sociedade Independente de Comunicação (SIC) led by Pinto Balsemão; 
TV1 Rede Independente, chaired by Proença de Carvalho with the support of the Carlos Barbosa media group (Presslivre), and Televisão Independente (TVI), close to the Catholic Church. The other potential candidate, Sonae group, announced in January 1991 that it would give up the competition. Sonae is a successful economic groups and the predictable lack of advertising revenues certainly contributed to its pulling out. Applying for a TV channel would be an expensive exercise and Sonae's chances of winning, whatever the quality of the project, would be very slim indeed. Sonae was - at the time - perceived as being close to the Socialist Party and the group's newspaper, Público, was often critical of government's policies. Hence, in spite of its economic strength, Sonae's political weight was limited.

The three candidates put forward quite different projects which the government, with the approval of the Alta Autoridade para a Comunicação Social (AACS), had to choose from.

The Proença de Carvalho candidacy (TV1) promised to broadcast from 8am to mid-night on a daily basis (on week-ends it could go until 2am). The channel would be generalist and popular. Programming would comprise news programmes (four news bulletins were predicted: three short ones and an extended one at night), telenovelas, talk-shows, movies, series and sports. According to the chairperson, the cornerstone of this project would be the emphasis on national production and the exclusivity of national capital. However, it was reported that there were contacts between Proença de Carvalho and Silvio Berlusconi, who would be prepared to make some investments in the Portuguese private television ${ }^{\text {xxix }}$ This project was not selected, although Proença de Carvalho is a well known public figure, close to the social democrats, and with experience in the television arena. During Balsemão's government, Proença de Carvalho was the head of RTP. His political weight is considerable and, if the Church had not been in competition, Carvalho's project would have been selected. Even if other strong candidates had run, this candidacy would have had a real chance.

Pinto Balsemão was the public face of the Sociedade Independente de Comunicação candidacy. SIC said that it was prepared to broadcast from $5.30 \mathrm{pm}$ to after mid-night. During week-ends, it would start at 3.30pm. Although SIC's general buzz-words were 'difference, popularity and intelligence', the main emphasis of this project was on information. Four news bulletins were predicted. SIC programming, 
which could be changed each time the news justified, would include series, talk-shows, competitions and movies. At this early stage, SIC had 17 shareholders, from which the most important were Soincom, SGPS (25\%); Globo Participações (15\%); Banco Mello (10\%); Espírito Santo Sociedade de Investimentos (6,25\%) and Banco Totta \& Açores (6,25\%). Pinto Balsemão himself has 2,5\% of the shares. According to Portuguese law, no national citizen or economic group is allowed to own more than $25 \%$ of the company, and no foreign company can invest in more than one TV channel nor is the foreign participation of any channel allowed to exceed $15 \%$ (law $n^{\circ} 58 / 90$, Art.9 ${ }^{\circ}$ ). This piece of legislation has been accepted with regard to non EU members. But TVI, for instance, has recently increased its foreign (EU) capital to approximately 40\%, arguing that 'non-discrimination' EU legislation is in contradiction with national laws. In any case, this argument cannot be used for non EU members and the Brazilian Globo network could only invest the maximum allowed by the Portuguese law.

Given that the negotiations between the Church and the government for a direct attribution of a TV channel failed, the Church went ahead with its candidacy. The main idea behind this project was to set up a channel of 'Christian inspiration' of true 'quality' and 'public utility'. Broadcasting was supposed to start on week days at 5pm and finish transmission around mid-night, whilst on week-ends it would go from 10am to $1 \mathrm{am}$. In terms of programming, three news bulletins a day were predicted and, like the other projects, it would include series, movies, sports, quizzes and talk-shows. Although this would not be a 'religious' channel, TVI considered in its candidacy space for religious content. TVI had also plans to co-operate with television stations from the Portuguese Speaking African Countries (PSACs). The most important shareholders of this project were Rádio Renascença, the União das Misericórdias, Editorial Verbo and Companhia de Jesus (institutions directly or indirectly related to the Catholic Church). The international shareholders were The Luxembourg Television Company (CLT) and the Spanish private television, Antena 3.

So, it was in this context that the Government and the High Authority for the Media (Alta Autoridade para a Comunicação Social) had to decide. Politicised and without resources and credibility, the AACS was not prepared to put forward its views on such a sensitive issue. But, as its opinion was required by the Constitution, the High Authority decided for 'technical equality' and no candidacy was excluded. The TV1 project (Proença de Carvalho) was considered 'deliberately ambitious', TVI's (Church) 
understood as 'modest' and SIC's (Balsemão) as 'balanced'. In this context, it was exclusively up to the government to decide on the issue. At that stage, the process was totally in control of the prime minister. Although in the beginning other senior politicians were involved, when final decisions were to be taken, Cavaco Silva managed the process himself.

On the 6th of February 1992, after a Cabinet meeting, ministro Marques Mendes, publicly announced the results: SIC had been attributed the third national channel and TVI got the fourth channel. According to Marques Mendes, these decisions were taken considering the AACS opinion and four additional criteria: technical quality, economic viability, type and characteristics of the programming and the candidates ability to satisfy diversity and public interest ${ }^{\mathrm{xxx}}$. But, for the opposition and for TV1, this result was no more than a 'political decision', taken without transparency. When the decisions were known, the editorial of Público newspaper stated: 'The government took the less politically damaging decision attributing the two private channels to the Church and to Balsemão, the candidates with more 'specific weight ${ }^{\mathrm{xxxi}}$.

At that time, attention was almost exclusively concentrated on who would gain control over the two new TV channels. This is hardly surprising given that - until then the state/government which owned RTP had effective editorial control over the company's output. If the same were to happen with the new TV stations, politicians holding office would have to be extremely careful as to who 'deserved' such a powerful instrument. All other crucial issues associated with the opening up of the market, such as sources of financing, balanced programming, and national production were neglected. Indeed, the government decided to attribute two licences and to abolish the television licence-fee without examining the conditions of the broadcasting market to support four national television channels. The Television Law (58/90 of 7 September), passed by Parliament, was so badly drafted that was totally ineffective and allowed TV channels to take the easier option: cheap imports and populist programmes. 


\section{Opening up the Telecommunications Market}

In line with what was being discussed in the EC at the time and following the Comissão para o Estudo do Desenvolvimento Institucional e Tecnológico das Comunicações (CEDITC) recommendations, the XI Constitutional Government decided to introduce major reforms in telecommunications sector.

Amongst the CEDITC recommendations, the first to be implemented was the separation of the regulatory and operational functions (until then the CTT/TLP exercised simultaneously both functions). The ICP gained effective legal existence through the law decree $283 / 89$ of 23 August $1989^{\text {xxxii }}$. This piece of legislation supposedly created an environment which would allow an even-handed introduction of competition in telecommunications services. The EU and indeed other pro-competition international actors had been arguing that the dual regulatory and commercial function of the telecommunications operator could not be sustained in a new competitive environment because of the conflict of interests. Although these arguments were accepted and ICP was set up before the directive on competition in the markets for telecommunications services (90/388/EEC of 28 June 1990) ${ }^{\text {xxxiii }}$, no real autonomy was granted by the Portuguese government to the regulatory institute.

According to the article 4 of law decree 283/89, ICP has a vast array of responsibilities to perform, namely to actively contribute to the sector's legal framework; to provide assistance to the government for the purposes of carrying out its tutelage responsibilities; to co-ordinate, on a national level, all matters concerning the carrying out of treaties, conventions and international agreements; to approve materials and equipment, to undertake the management of the radio electric spectrum; to license public sector communications operators in addition to providers of value added services; among others. The difficulty however is that, with the exception of technical matters, the ICP has merely an advisory/supportive role. No line has been clearly drawn between what is a policy and a regulatory issue. Furthermore, the members of the board of directors are appointed by a resolution of the Council of Ministers (article 6, law decree 283/89). So, even with its legally recognised administrative and financial 
autonomy $^{\mathrm{xxxiv}}$ and despite feasible strains, the ICP cannot be said to be a truly independent body.

Immediately after the legal setting up of ICP, the Basic Law on the establishment, management and exploitation of telecommunications infrastructures and services (88/89 of 11 September 1989) was approved by the National Assembly. This Telecommunications Act can be understood as a real watershed in the Portuguese telecommunications legal history because, for the first time, the general principles for the sector were compiled in the same piece of legislation. According to this law, it is the responsibility of the state to guarantee the existence and availability of fundamental services, including fixed telephone services, telex and a switched data transmission service (article 8). However, the exploitation of services involving the use of complementary telecommunications infrastructures ${ }^{\mathrm{xxxv}}$ may be carried out by public and private companies, once properly licensed (article 10).

Similarly, the provision of value added services ${ }^{\mathrm{xxxvi}}$ may be made by any singular person or collective body (under specific conditions) and by the public telecommunications carriers and complementary telecommunications companies (article 13). To sum up, apart from the fundamental services, which would continue to be provided by the state, other actors - either private or public - could from then on apply to become services providers. Only the telecommunications infrastructure was to remain firmly under the responsibility of the public telecommunications carrier (article 7).

Although new entrants would have to comply with specific rules and regulations, the Telecommunications Act sets out some requirements concerning protection of competition. It states that public telecommunications carriers should guarantee the use of their networks for all communications carriers under equal competitive conditions. When public carriers provide complementary services they are equally forbidden to use any practice which may distort conditions of competitiveness or which are considered to be an abuse of a leading position (article 14). These legal provisions have not prevented alleged abuses of dominant position and accusations of unfair competition have been frequently reported. The implementation of these general principles - particularly those related to complementary and value-added services required further legislation which 'should be made in accordance with the development 
of market requirements and obligations created by Community legislation' (Law 88/89, article 21$)^{\mathrm{xxxvii}}$.

These legal instruments - notwithstanding their significance - were not particularly controversial as the changes were perceived both as necessary and inevitable by both the government and the opposition main party, the Socialist Party. In general terms, it can be argued that the creation of ICP and the liberalisation of complementary and value-added services were directly and indirectly related to the EU legal framework. If Portugal had not passed this legislation, it would have had to comply later on with the ONP Council directive (90/387/EEC), with the Commission's Services directive (90/388/EEC) and subsequent legislation. Directives are indirectly binding in the sense that it is up to the member states to decide how the intended results of the legislation are to be achieved. In the Portuguese case, the liberalisation was nevertheless quite limited as, before the partial privatisation of Portugal Telecom, only $3 \%$ of the telecommunications market was in the private sector ${ }^{\mathrm{xx} x \mathrm{vii}}$.

Even if these changes were ultimately introduced by the national parliament and government, it is quite clear that the EU played a role here. For the reasons we have previously analysed (ideological, political and economic), the EU persuasively convinced the member states that no alternative existed but to open up their markets. Core countries had very concrete interests in doing so whilst peripheral countries were convinced that they had not much to lose. So, the Council ended up approving legislation that would make it more difficult for member-states to take protectionist measures. For Portugal, the liberalisation process was perceived as inevitable once no other alternatives existed ${ }^{\mathrm{xxxix}}$.

In addition to the opening up of the telecommunications market to new entrants, the Portuguese authorities believed that the three traditional public operators (CTT, TLP and Marconi ${ }^{\mathrm{xl}}$ ) had to go through a re-organisation process. These operators were - for historical reasons - organised on a geographical basis ${ }^{\text {xli }}$ which was considered by the government as inappropriate. So, a financial holding society, Comunicações Nacionais (CN) was set up in 1992 (Law decree 88/92 of 14 April 1992) mainly to coordinate the sector, to define investment/business strategies and to deal with the privatisation process. CN started its operations in early 1993 comprising five independent public companies: the former postal services of Correios $e$ 
Telecomunicações de Portugal (CTT), now an independent company (also called CTT), Telecom Portugal (TP), the telecommunications arm of the earlier $\mathrm{CTT}^{\mathrm{xlii}}$, Teledifusora de Portugal (TDP) ${ }^{\mathrm{xliii}}$, Telefones de Lisboa e Porto (TLP) and Marconi.

The creation of CN was defended by its chairperson, Cabral da Fonseca ${ }^{\text {xliv }}$, as being the 'rational' choice for the sector. The two other alternatives were to maintain the historical scenario or to merge the companies, but the holding company was - according to him - the only solution with small disadvantages ${ }^{x l v}$. This view, however, would not be maintained for long as Telecom Portugal would soon put in place its strategy to become the dominant actor in the Portuguese telecommunications scene. The president of Telecom Portugal from 1990 to 1992, Gonçalo Areia, had already publicly argued for the setting up of a single telecommunications operator ${ }^{\text {xlvi }}$. But it would be the next president, Luís Todo Bom, (also vice-president of the party in power) who would convince $\mathrm{CN}$ and the government that the company he chaired was the only one that could adequately lead the re-organisation process. The plan was to take over TDP, TLP and Marconi.

Despite Marconi's opposition and fierce criticisms from the government's own ranks, the merger went ahead. On the 20th of November 1993, in a long interview to Expresso, Cabral da Fonseca, argued that more than one company providing basic services in a country with ten million inhabitants and with the Portuguese GDP was unthinkable: 'there is no way of surviving in a competitive environment'. The CN's president previously believed that Portugal should have two basic service operators, one international (possibly the historic Marconi) and one national (possibly a new company resulting from the merger between TP and TLP) ${ }^{\text {xlvii }}$. No case was put forward to defend his new point of view but it became quite clear whose lobbying was more efficient. Interestingly enough, Luís Todo Bom has also never put forward a clear set of arguments to justify publicly why - in a country which has traditionally had three operators - a single PTT would provide a better service. He has argued, in very general terms, that Portugal should follow the Dutch model which is based on a single PTT and, furthermore, that the creation of a single telecommunications operation was essential to fight foreign competition when the market is fully liberalised between 1998 and $2003^{\text {xlviii }}$. 
Neither the government nor the operator which has benefited the most from the reorganisation (PT) have been able to justify the paradox of arguing simultaneously for liberalisation and for concentration. On the one hand, it has been argued that liberalisation and full competition can only benefit the consumer; on the other hand, it has been argued that only a big operator can respond to the challenges imposed by liberalisation. In any case, because the re-organisation process was designed behind closed doors with no public debate and adequate consideration for long standing actors in the field, there was no need to prepare a consistent case. The process was conducted with speed but it certainly lacked participation.

Just as with the re-organisation of the sector, the partial privatisation of Portugal Telecom is not a direct result of EU policies. According to O Siochrú, the only acknowledged problem the EU has expressed about LFRs concerned where they would find the resources to 'keep pace' with liberalisation - 'and indeed this may be no more than a veiled reference to privatisation ${ }^{\text {'lix }}$. But, even if the EU has tried to convince its members to privatise, it has no open policy on the issue and member states can decide their own strategies. Portugal has decided to enter the North American/European bandwagon.

The ministro Ferreira do Amaral has publicly stated that - whether we want it or not - the telecommunications sector will be exclusively private because public companies have no agility nor vocation to stand a chance in a competitive market. "This is happening in all countries in the world. I do not know any [country] which is, at this stage, thinking about nationalising the telecommunications sector and the vast majority is thinking about privatising' (speech delivered at the APDC conference in Lisbon, November 1994). From this speech, two features emerge: i) if most countries are privatising, Portugal must do it as well, ii) even if Portugal resists privatisation, it would happen anyway. Yet, Ferreira do Amaral has not attempted to explain the benefits of privatisation and he has not attempted to explain why public companies (whose managers have been appointed by the social democrats over the last decade) have performed poorly. The telecommunications sector in the country was in private hands since the 19th century up until the 1960's, and in the public sector ever since. In both periods it has performed deficiently. 
On the 20th of March 1995, just before the privatisation went ahead, the government granted PT a public service concession contract for 30 years (due for renewal in 15 years). According to this contract ${ }^{\mathrm{li}}$, PT has the exclusive right to provide basic telecommunications services and to manage all telecommunications infrastructures which support these services because the infrastructures will remain in the public domain ${ }^{\text {lii }}$. The company will have the monopoly of basic services until this area is liberalised in January 2000.

After the first stage of PT's privatisation, on the 13th of July 1995, the Council of Ministers approved the abolition of Comunicações Nacionais. CN had been coordinating the restructuring of the sector and preparing the privatisation of PT. Still, CN had not been able to actually lead the process and was too weak to fight lobbies and balance the needs and interests of the various actors involved in national telecommunications. Ferreira do Amaral, quoted in Público ${ }^{\text {liii }}$, argued that CN would come to an end because it has accomplished its mission (14 July 1995:32). Furthermore, Cabral da Fonseca stated that he would calmly assist the evolution of the sector because 'the essential had already been done and it is irreversible' liv .

\section{Guterres Government: Tuning up Reforms}

As we have mentioned earlier, major reforms in the media/communications system were indeed introduced by the two Cavaco Silva's majority governments. The Socialists have hence inherited a transformed yet poorly regulated arena and weak regulatory bodies. António Guterres' government programme ${ }^{\text {lv }}$ did not contemplate any significant changes in the media/communications system instead proposing to strengthen existing regulatory bodies and to improve legal tools.

The government's programme referred to communications in three different dimensions $^{\text {lvi. }}$ : mass media, telecommunications and information society. In terms of mass media ${ }^{\text {lvii }}$, the Guterres government considered the following priorities: right of information, revitalisation of the media sector, independence in the management of the media public sector, and the media as a toll of international politics. In order to accomplish these objectives, the government intended to take the following measures: 
a) to pass a new Press Law which guarantees in an innovative manner freedom of information and journalists rights;

b) to modify the composition of the High Authority for the Media (which was perceived as being highly politicised);

c) to revise the role of the High Authority for the Media in order to widen its powers and influence;

d) to provide financial incentives to local/regional radio stations;

e) to revise the Public Service Television contract between RTP and the State;

f) to establish a Public Service Radio contract between RDP and the State;

g) to develop management models which might guarantee the independence of public broadcasters from the government;

h) to develop an integrated audio-visual, television and telecommunications policy;

i) to alter the statute and the capital structure of the news agency Lusa;

j) to promote in the ratification of the European Convention on Transfrontier Television;

k) to develop the co-ordination of RDP, RTP and Lusa international services;

l) to guarantee an independent and pluralist information for Portuguese communities abroad, paying particular attention to the Portuguese language and culture, and to the Portuguese speaking African countries.

In terms of telecommunications ${ }^{\text {viii }}$, the government programme stated that it would promote the necessary measures in order to guarantee real competition in telecommunications services, and that it would introduce liberalisation in communications services, according to EU directives and market changes. In order to achieve the stated goals, a number of initiatives were predicted:

a) promotion of the needed measures to ensure that competition is the rule in the communications services;

b) progressive liberalisation of telecommunications services; 
c) establishment of strategic alliances to guarantee the participation of Portugal in the international communications business;

d) encouragement of the national communications equipment industry;

e) support to the establishment of a national content industry.

Regarding the so-called information society ${ }^{\text {lix }}$, the government programme considered that IT was absolutely crucial to the development of a 21st century society. As such, the new technological potential would be put to use in order to transform social and economic life:

a) reinforcing the scientific and technological infrastructure;

b) increasing the usage of information technologies by citizens and companies;

c) using IT to modernise Public Administration;

d) training people for the development of an Information Society

Though it is still early to analyse the 1995-1999 socialist mandate, one might look back and attempt to examine some aspects of the implementation of these electoral guidelines. In the broadcasting arena, a new television Act was passed (Law 31-A/98 of 14th of July). The new television Act introduced changes in both the access to and exercise of the television activity. For the first time, the possibility of creating local, regional and thematic channels was consecrated by law. Up until Law 31-A/98 was approved, the Portuguese television broadcasting system already included a number of channels: two public national channels (RTP1 and RTP2), two private national channels (SIC and TVI), two public regional channels (RTP-Açores and RTP-Madeira), and two public international channels (RTP África and RTP Internacional). Cable television and satellite television reception were also well established realities but companies were not allowed to produce their own programmes. Only third party transmissions were legally possible $e^{\mathrm{lx}}$.

The new television law has opened up the thematic channels' flood gate. Terrestrial television companies are therefore associating themselves with cable operators and international content producers in order to guarantee their places in the new broadcasting scenario. SIC, for example, has associated itself with the Brazilian 
network TV Globo and the biggest national cable operator,TV Cabo, in order to develop the Premium TV project.Premium TV is offering two codified movie channels (Telecine1 and Telecine2) since June 1998. RTP has, in February 1998, signed a contract with TV Cabo, and with a company with multiple interests in sports, Olivedesportos. This consortium is operating, since September 1998, a codified Sports channel, Sport $T V^{l x i}$. According to the Secretário de Estado da Comunicação Social, Arons de Carvalho, local/regional television channels are not expected to be licensed before 2005 or $2006^{\text {lxii }}$.

The proliferation of television channels does not necessarily mean that the financial situation of broadcasting companies has improved during the Guterres' mandate. In fact, TV stations such as RTP and TVI have had important financial losses over recent years. The advertising market is small and, apart from SIC, terrestrial broadcasting companies have had highly unstable management mainly due to the lack of advertising revenues and debt accumulation. When the broadcasting market was opened up to private initiative, in 1992, the Cavaco Silva government abolished the television license-fee and sold RTP's transmission network to Portugal Telecom. These political decisions, which were not reversed by the current government, put RTP in a difficult economic situation and transformed a so-called Public Service Broadcasting into a standard commercial television, i.e., RTP had to fight for audiences trying to conquer a meaningful slice of the adverting cake. With this strategy, RTP was neither performing its duties as a public service nor being successful as a commercial company.

Socialist António Guterres’ government tried to modify RTP's ambiguous strategy, preparing a new Public Service Contract between the State and the public operator. 'Public service' as a set of tasks, as contemplated in the previous contract, was abolished with the signing up of a new Public Service contract in December 1996. Unlike the previous one, the new contract sees Public Service as a mission, as a programming philosophy. The contract defined more clearly RTP's objectives but it has not solved its financial problems.

Apart from the new television law, the government has also expressed some concern with digital television. Although terrestrial digital television is not expected to be introduced before 2001, the prime minister has announced, on August 1998, that it would be introduced 'as soon as possible'. As a result, the Instituto da Comunicação Social (Media Institute, known as ICS) and the Portuguese Communications Institute 
(ICP) co-ordinated a public consultation process on Digital Video Broadcasting Terrestrial (DVB-T) from August up until October 1998.

Not unlike its Social Democrat predecessors the Socialist government also considered international broadcasts of great importance to its foreign policy. Under the PSD's tutelage, RTP's International channel (RTP Internacional) and RDP's international channel (RDP Internacional) were launched. Recognising the relevance of these instrument, António Guterres supported their expansion and consolidation. Most Portuguese communities abroad and Portuguese speaking nations can effectively watch and listen to these international television and radio channels. In addition, the current government decided, along with RTP and RDP, to set up channels (RTP África and $R D P$ África) specifically designed for Portuguese speaking African countries (Angola, Mozambique, Guinea-Bissau, Cape Verde and S. Tomé and Príncipe). RTP África and $R D P$ África are indeed establishing themselves as news and programming sources in Lusophone Africa. Lusa news agency is also reinforcing its links with Portuguese speaking African countries.

In the radio broadcasting sphere, the socialist government has also developed and/or revised a number of legal tools. Basically, it made it compulsory for local radios to produce their own content (most were simply broadcasting national radio stations feed) and created financial incentives, namely subsidising technological modernisation, providing institutional advertising, and reducing telecommunications costs (due to an agreement with Portugal Telecom).

As stated in the government programme, independence in the media public sector and journalists' rights were also high on the agenda. Therefore, both the Press Law and the Journalists' Statute were altered. These revised tools intended to expand pluralism and independence within media companies and to reinforce journalist's rights. Changes in the Media regulatory body, High Authority for the Media, were introduced as well. Indeed, this entity was perceived as highly politicised and its influence was very limited. The 1995-1999 socialist government altered its composition and widen its powers. It should be noted that most of these changes are yet to be proved effective. In fact, the shadow of State control still hangs over both RTP and RDP and periodical allegations of interference have been made by journalists during this four year period. 
In the telecommunications arena, it might be argued that Law-decree 381-A/97 of the 30th of December was particularly relevant. This law-decree established the new telecommunications access regime for the activity of a public telecommunications networks operator and provider of public telecommunications services, and aimed at simplifying the access to the telecommunications market. From then on, a number of telecommunications services no longer required authorisation from the telecommunications regulator (Instituto de Comunicações de Portugal). Apart from fixed telephony, public networks and services implying the attribution of frequencies, all other telecommunications services have to be registered at ICP, but not authorised by the regulator. The 'freedom of establishment' principle aims at reducing bureaucracy and allow for an easier entrance of new actors into the market. The Law-decree 381$\mathrm{A} / 97$ is in itself a transposition of EU regulation to the national legislative body, namely directives 96/2/EC (mobile and personal communications), 96/19/EC (introduction of full competition in the telecommunications market), and 97/13/EC (common framework for authorisations and licenses in terms of access to the telecommunications market) ${ }^{\text {lxiii }}$.

In September 1998, a new mobile phone operator entered the market. Optimus, a Sonae group project, forced the other two operators (Telecomunicações Móveis, TMN and Telecel) to reduce tariffs. Due to an aggressive pricing policy, right before starting operating, Optimus already had half a million so-called 'pre-adherents', i.e., people who have put in writting their intention to become an Optimus client. Despite substantial investments (expected to be between 350 million Euros and 500 million Euros in the first three years), the Sonae holding is predicting Optimus to break-even by 2001.

In the Information Society arena, some measures were effectively taken. In 1997, the Portuguese government published the Information Society Green Paper, an attempt to develop and implement policies within the 'Information Society' framework. In the aftermath of this green paper, a number of political measures were introduced and implemented in 1998. The National Science, Technology and Society Network, is being set up. This scientific network plans to bring together national researchers and to stimulate and consolidate R\&D. In a move very similar to the one being developed in Britain, the Ministério da Ciência e da Tecnologia (Science Ministry) is also making an effort to introduce the Internet in every school of the country (from the 5th to the 12th 
grade), universities, libraries, and research centres. 'Computers for all' is another project being developed. The 'Computer for all' project has the objective of increasing the number and usage of Internet connected computers at home. In addition, a considerable number of small-scale initiatives, such as the creation of telework centres, are under way. Around $20 \%$ of the population has access to the Internet, though only $10,6 \%$ use the Internet regularly. The Internet is mostly used at school, then at work and thirdly at home. Internet is most relevant in the education sector (amongst academics and students) and in the service sector (e.g., banking, insurance, advertising and travel

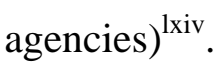

\section{Conclusions}

This article started by presenting a general overview of the media and telecommunications' recent history as we believe that any a-historical attempt to examine current communications in Portugal is bound to be faltering. Then, we tried to demonstrate that structural changes in the media and communications were introduced during the Cavaco Silva majority governments. Due to external and internal factors, changes were seen as inevitable. From telecommunications to the press, all media/communications sub-sectors were transformed.

When António Guterres came to power in 1995, it had reduced room for manoeuvre. Major changes in the markets structure had already been introduced (and most were understood as irreversible), and the EU was intervening more frequently and more consistently in the communications arena. Therefore, in the telecommunications domain, the 1995-1999 government basically followed EU directives whilst in the media (as the EU is far less influential in this sector) it attempted to improve perceived deficiencies inherited from the previous government.

Notwithstanding the refereed differences between Cavaco Silva and Guterres governments concerning actual intervention in communications, there are also some distinct aspects regarding the mode of governance. During the Cavaco Silva rule, political power was largely concentrated in the hands of the prime minister and a few 
senior politicians. Despite the formal dispersion of power (a number of Secretarias de Estado and government bodies were involved in policy-making), all fundamental aspects of communications/media policy (e.g. the opening up of television to private initiative) were dealt with by the prime minister himself. Most decisions were taken behind close doors with no justification being provided.

The Guterres government tried since early days to involve social actors in the decision-making process. 'Dialogue' has been a key word and it has some meaning in the communications arena. Indeed, and despite the continual formal fragmentation of power in this policy-area, the different Secretarias de Estado involved in the sector have been trying to implement a more open decision-making process, promoting public consultations and publicising the distinct stages of the political process.

\section{Bibliography}

Assembleia da República (1981) Programa do VII Governo Constitucional, Apresentação e Debate, AR-Divisão de Edições, Lisbon.

Assembleia da República (1987) Programa do XI Governo Constitucional, Apresentação e Debate, AR-Divisão de Edições, Lisbon.

Assembleia da República (1992) Programa do XII Governo Constitucional, Apresentação e Debate, AR-Divisão de Edições, Lisbon.

Assembleia da República (1995) Programa do XIII Governo Constitucional, Apresentação e Debate, AR-Divisão de Edições, Lisbon.

Bruneau, T. and MacLeod, A. (1986) Politics in Contemporary Portugal, Parties and the Consolidation of Democracy, Boulder, Lynne Rienner.

Carvalho, A. A. (1999) Communication delivered at the VII Congresso Nacional de Rádios, 27-28 February, Óbidos, Portugal.

Noam, E. (1992) Telecommunications in Europe, Oxford, Oxford University Press.

Optenhogel, U. (1986) 'Portugal' Kleinsteuber, H.J. et al. (eds) Electronic Media and Politics in Western Europe, Frankfurt, Campus Verlag, pp.239-250. 
O Siochrú, S. (1993) 'The EC’s Telecommunications Policy and Less Favoured Regions: the Role of the STAR Programme', paper delivered at the IAMCR Conference, Dublin, 2426 June.

Mesquita, M. (1988) 'Estratégias liberais e dirigistas na Comunicação Social de 1974-1975, da Comissão Ad Hoc à Lei de Imprensa in Comunicação e Linguagens, nº, December, pp. 85-113.

Mesquita, M. et al. (1994) 'Os meios de Comunicação Social’ in António Reis (ed.) Portugal, 20 anos de Democracia, Lisbon, Círculo de Leitores, pp. 360-405.

Ministério das Obras Públicas, Transportes e Comunicações (1987) Desenvolvimento Institucional e Tecnológico das Comunicações, Lisbon, MOPTC.

Presidência do Conselho de Ministros (1992) 'Atribuição dos novos canais de Televisão', Press Release, 6 February.

Santos, R. (1989) 'Entre a Telefonista e a Central Digital - TLP: A História de uma empresa centenária’, unpublished communication, Vila Nova de Gaia.

Sousa, H. (1999) 'Portugal’ European Audiovisual Sector 1998: Regulation and Practice, European Audiovisual Observatory, Council of Europe, (forthcoming).

TLP (1992) 1882-1992, 110 Anos a Telecomunicar, Lisbon, TLP.

\footnotetext{
${ }^{\text {i } M e s q u i t a, ~ M . ~ e t ~ a l . ~(1994), ~ ' O s ~ M e i o s ~ d e ~ C o m u n i c a c ̧ a ̃ o ~ S o c i a l ' ~ i n ~ R e i s, ~ A . ~(e d .) ~ P o r t u g a l, ~} 20$ Anos de Democracia, Lisbon, Círculo de Leitores, pp. 360-361.

${ }^{\mathrm{ii}}$ It is important to remember that the regime collapsed with almost no resistance. Therefore, former supporters of the regime were amongst the 'winners' of the revolution.

iii The 1975 Press Law was revised several times.

iv Quoted in Bruneau, T. and MacLeod, A. (1986), Politics in Contemporary Portugal, Parties and the Consolidation of Democracy, Boulder, Lynne Rienner, pp. 165-166.

v Mesquita, M. (1988), 'Estratégias liberais e dirigistas na Comunicação Social de 1974-1975, da Comissão Ad Hoc à Lei de Imprensa’, Comunicação e Linguagens, nº 8, December, p. 89.

${ }^{v i}$ Quoted in Mesquita, M. (1988), Ibid., p. 102.

${ }^{\text {vii }}$ Mesquita, M. (1988), Ibid., p.107.

viii Mesquita, M. et al. (1994), Op. Cit., p. 368.

${ }^{\text {ix }}$ Mesquita, M. et al., Ibid.

${ }^{x}$ Optenhogel, U. (1986), 'Portugal', Kleinsteuber, H.J. et al., Electronic Media and Politics in Western Europe, Frankfurt, Campus Verlag, p. 243.

${ }^{\mathrm{xi}}$ Quoted in Bruneau, T. (1986), Op. Cit, p. 173.
} 
xii See Assembleia da República (1991) Programa do VII Governo Constitucional, Apresentação e Debate, Lisbon, AR-Divisão de Edições.

xiii Digitalisation is the process of converting from analogue to digital techniques; e.g. upgrading of part or whole of a telephone network so that sound, images and data are transmitted in the form of discrete binary data (bits).

${ }^{\text {xiv }}$ Optic fibre or fibre optics is the technology of using hair-like, light-transmitting, glass fibres to transmit information; light beams are used to carry voice or data down fibre optic 'pipes'.

${ }^{\mathrm{xv}}$ The two traditional telecommunications manufacturers in Portugal were ITT's Standard Electric and the British Plessey. Plessey left the country in 1979 when the factory was sold for $£ 1$ to the local firm, Centrel.

xvi Personal interview with Tribolet, J., chairperson of INESC, Instituto de Engenharia de Sistemas $e$ Computadores. The interview took place in Lisbon, on the 17th of November 1994.

xvii These companies were Standard Electrica, Ericsson, AT\&T/Philips, Northern Telecom, Siemens, Plessey and Alcatel/Thomson.

xviii Noam, E. (1992), Telecommunications in Europe, Oxford, Oxford University Press, p. 261.

${ }^{x i x}$ See Noam, E., Ibid., pp.260-261.

${ }^{x x}$ Santos, R. (1989), 'Entre a Telefonista e a Central Digital - TLP: A História de uma empresa centenária', unpublished communication, Vila Nova de Gaia.p.10.

${ }^{x x i}$ TLP (Telefones de Lisboa e Porto) (1992) 1982-1992, 110 Anos a Comunicar, Lisbon, TLP, p. 75.

xxii Tribolet, J., interview, Op. Cit.

xxiii These figures were estimated, utilising data from Sabatina and the opinion of several experts in the field.

xxiv Ministério das Obras Públicas, Transportes e Comunicações (1987), Desenvolvimento Institucional e Tecnológico das Comunicações, Lisbon, MOPTC.

${ }^{x x v}$ See Assembleia da República (1987), Programa do XI Governo Constitucional , Apresentação e Debate, Lisbon, AR-Divisão de Edições, p. 33.

${ }^{x x v i}$ The first majority government since 1974 ran the country between 1987 to 1991; the second majority government was in power from 1991 to 1995 (these were respectively the XI and XII Constitutional governments).

xxvii See Assembleia da República (1987), Programa do XI Governo Constitucional , Apresentação e Debate, Lisbon, AR-Divisão de Edições, and Assembleia da República (1992), Programa do XII Governo Constitucional , Apresentação e Debate, Lisbon, AR-Divisão de Edições

xxviii Público, 7 February 1992, p. 5.

xxix See, for example, Público, 6 February 1992, p. 22.

xxx Presidência do Conselho de Ministros (1992) ‘Atribuição dos novos canis de televisão’, Press Release, 6 February.

xxxi Público, 7 February 1992, p. 3.

xxxii ICP was formally created in 1981 under the law decree 181/81 of 2nd of July but this legislation has not produced any results until the 1989 go ahead.

xxxiii In addition to the opening up of the telecommunications services, this directive also contemplates the separation of regulatory and commercial functions.

xxxiv ICP has to generate its own financial resources which is achieved mainly from the spectrum management (spectrum users pay ICP directly) and from the issuing of licenses.

${ }^{\mathrm{xxx}}$ In accordance with the Portuguese law, complementary telecommunications infrastructures are all public telecommunications infrastructures which are not part of the basic telecommunications network. Basic telecommunications network is comprised of a fixed system of access by subscribers and by the transmission network including, in addition, concentration, switching or processing nodes which are essentially meant for the provision of the fundamental services (fixed telephone, telex and one switched data transmission service) (law 88/89, article 9 and 11)

${ }^{\mathrm{xxxvi}}$ Value added services are understood - by the Portuguese law - to be those which, using fundamental or complementary services as their only support, do not require their own telecommunications infrastructures and which are distinguishable from the services on which they are based (law 88/89, article 13).

xxxvii See, inter alia, law decree 346/90 of 3 November 1990; law decree 147/91 of 12 April 1991;

regulation 240/91 of 23 March 1991; law decree 329/90 of 23 October 1990.

xxxviii Diário de Notícias, 19 November 1994, p. 12 (Negócios).

xxxix See speech of Ferreira do Amaral on the 5th APDC Congress in Lisbon, November 1994.

${ }^{\mathrm{xl}}$ Marconi was considered a public operator but $49 \%$ of its shares were in private hands.

${ }^{\mathrm{xli}} \mathrm{CTT}$ used to supply local telephony to the entire country with the exception of the two main cities, 
Lisbon and Oporto, and long distance communications to Europe and North Africa; TLP used to cover Lisbon and Oporto while Marconi had the monopoly of cable and satellite communications to the rest of the world.

xlii The separation of the CTT's post and telecommunications activities was contemplated in the law decree 277/92 of 15 December 1992.

xliii TDP was set up through law decree 138/91 of 8 April 1991 in order to distribute broadcasting signals for RTP and for the forthcoming television companies, if they wished so.

${ }^{x}$ Cabral da Fonseca was perceived as an ally of Ferreira do Amaral and, before chairing CN, was the chief of the Portuguese commissioner's cabinet in Brussels.

${ }^{\mathrm{xlv}}$ See Público, 9 December 1992.

xlvi Expresso, 19 December 1992, pp. Economia.

xlvii See Público, 10 September 1993, p. 35; Público 30 October 1993, p. 39.

xlviii Público, 10 September 1993, p. 35.

xlix O Siochrú, S. (1993), 'The EC’s Telecommunications Policy and Less Favoured Regions: the Role of the STAR Programme’, paper delivered at the IAMCR Conference, Dublin, 24-26 June, p. 4.

${ }^{1}$ Speech delivered at the APDC conference in Lisbon, November 1994.

li See law decree 40/95 of 15 February.

${ }^{\text {lii } W h a t ~ w a s ~ p r i v a t i s e d ~ w a s ~ t h e ~ p r o v i s i o n ~ o f ~ t h e ~ s e r v i c e s, ~ n o t ~ t h e ~ i n f r a s t r u c t u r e s . ~}$

liii Público, 14 July 1995, p 32.

liv Público, 14 July 1995, p. 32.

lv Assembleia da República (1995), Programa do XIII Governo Constitucional, Apresentação e Debate, Lisbon, AR-Divisão de Edições.

${ }^{\mathrm{lvi}}$ In this article cinema is not considered as it is still very much perceived as part of the cultural realm.

lvii Assembleia da República (1995), Op. Cit., I, 8.3.

lviii Ibid., III, 7.2.

lix Ibid., V, 3.

lx Sousa, H. (1999), 'Portugal', European Audiovisual Observatory, European Audiovisual Sector 1998: Regulation and Practice, Council of Europe (forthcoming).

lxi Ibid.

lxii Carvalho, A. A. (1999) Communication delivered at the VII Congresso Nacional de Rádios, 27-28

February, Óbidos, Portugal.

lxiii Sousa, H. (1999), Op. Cit.

lxiv Ibid. 